conducted but have not yet influenced clinical practice or public health medicine, largely because of the low statistical power associated with their small sample sizes.

Better, larger scale studies are widely acknowledged to be necessary, but how are these to be conducted? Potential researchers need to be aware of methodological difficulties, and their likely solutions, and if truly informative studies are to be undertaken a consensus needs to be established if large scale research enterprises are to bear fruit. Under the auspices of the Medical Commission of the European Community, Eurodem, guided by Albert Hofman, has laid out the path for later researchers to follow. Eurodem's route is a collaborative reanalysis of a small number of case-control studies of the epidemiology of Alzheimer's disease. ${ }^{12}$ Although the approach is limited by the variable quality of the original data it has the important strength of establishing "the consistency of findings." 13 Except for family history, ${ }^{1+}$ none of the hypothetical risk factors examined are convincingly linked to Alzheimer's disease, but this should not deter the prospective researcher or funding agency.

The Eurodem endeavour will be influential not because of the validation of the size of the effect of a specific risk factor but because of the care with which the authors have set out relevant methodological problems. Their reanalyses are reported with great caution, yet some issues stand out clearly. Case definition will remain imprecise and lead to far too many false negative cases until the present (provisional) clinical criteria $^{11}$ include pathognomonic objective tests. As geneenvironment interaction provides the likeliest pathogenic model, ${ }^{14}$ future epidemiological studies must be supported by molecular biological investigations.

A recent meeting in Bethesda sponsored by the National Institute of Aging and the World Health Organisation gave the authors of the Eurodem report a chance to air their concerns about future epidemiological studies. Epidemiological principles can be used successfully to investigate relations between genetic susceptibility and putative risk factors. ${ }^{15}$ Simple genetic models can be applied to data where variation in genetic susceptibility is precisely known (such as the presence of a genetic mutation $\left.{ }^{3}\right)$. Hofman emphasised the importance of vascular disorders not only as possible models for Alzheimer's disease but also as likely causal processes. ${ }^{1617}$
Exposure to noxious agents has become a matter of great public concern that transcends national boundaries. Experimental neuropathology provides the vital impetus towards successful identification of toxins that might contribute to neurodegenerative disorders, ${ }^{18}$ but epidemiology has a major part to play. Hofman and his colleagues may not have established that any particular risk factor (other than family history) is of major importance in Alzheimer's disease, but they have certainly set out the directions that future research might most reasonably follow.

Senior Lecturer in Psychiatry,

L J WHALLEY

Royal Edinburgh Hospital,

Edinburgh EH10 9HF

1 Deary IJ, Whalley LJ. Recent research on the causes of Alzheimer's disease $B$ M7 1988;297:807-10.

2 Henderson AS. The risk

Scand 1988;78:257-75.

Goate A Chartier-Harlin M-C Mulla M, Bown J, Crawford F, Fidan missense mutation in the amyloid precursor protein gene with familial Alzheimer's disease. Vature $1991 \cdot 349 \cdot 704-6$

4 Murrell J, Farlow M, Ghetti B, Benson MD. A mutation in the amyloid precursor protein associated with hereditary Alzheimer's disease. Science 1991;254:97-9.

Chartier-Harlin M-C, Crawford F, Houlden H, Warren A, Hughes D, Fidani L, et al. Early-onset Alzheimer's disease caused by mutations at codon 717 of the $\beta$-amyloid precursor protein gene. Nature 1991;353:844-6

6 St George-Hyslop PH, Haines JL, Farrer LA, Polinsky R, Van Broeckhoven C, Goate A, et al. ? Genetic linkage studies suggest that Alzheimer's disease is not a single homogeneous disorder. $\vec{N}$ Nature 1990;347:194-7.

Nee LE, Eldridge R, Sunderland T, Thomas CB, Katz D, Thomson KE, et al. Dementia of the Alzheimer type; clinical and family study of 22 twin pairs. Neurology 1987;37:359-63.

8 Davidson EA, Robertson EE. Alzheimer's disease with acne rosacea in one of identical twins f Neurol Neurosurg Psychiatry 1955;18:72-7.

9 Calne DB, Eisen A, McGeer E, Spencer P. Alzheimer's disease, Parkinson's disease and motoneurone disease: abiotrophic interaction between aging and environment? Lancet 1986;ii: 1067-70

10 Kay DWK, Beamish P, Roth M. Old age mental disorders in Newcastle-upon-Tyne. I. A study of prevalence. Brf Psychiatry 1964;110:146-58.

11 McKhann G, Drachman D, Folstein M, Katzman R, Price D, Stadlan E. Clinical diagnosis of Alzheimer's disease: a report of the NINCDS-ADRDA work group under the auspices of Department of Health and Human Services Task Force on Alzheimer's disease. Neurology Department of Health and Human Services Task Force on Alzheimer's disease. Neurology

12 van Duijn CM, Hofman A. Risk factors for Alzheimer's disease: a collaborative re-analysis of casecontrol studies. Int f Epidemiol 1991;20(suppl 2):1-73.

3 Clayton D. The Eurodem collaborative re-analysis of case-control studies of Alzheimer's disease: some methodological considerations. Int f E pidemiol 1991;20(suppl 2):62-4.

14 van Duijn CM, Clayton D, Chandra V, Fratiglioni L, Graves AB, Heyman A, et al. Familial aggregation of Alzheimer's disease and related disorders: a collaborative re-analysis of casecontrol studies. Int f Epidemiol 1991;20(suppl 2):13-20.

15 Ottman R. An epidemiologic approach to gene-environment interaction. Genet Epidemio 1990;7:177-85.

16 Aronson MK, Ooi WL, Morgenstern H, Hafner A, Masur D, Crystal H, et al. Women, myocardial infarction and dementia in the very old. Neurology 1990;40:1102-6.

17 Sparks DL, Hunsaker JC 3rd, Scheff SW, Kryscio RJ, Henson JL, Markesbery WR. Cortical senile plaques in coronary artery disease, aging and Alzheimer's disease. Neurobiol Aging 1990;11:601-7.

18 Olney JW. Excitatory amino acids and neuropsychiatric disorders. Biol Psychiatry 1989;22:505-25.

\title{
Reforming health care in the United States
}

\section{The American College of Physicians wants universal access to basic health care}

At its best American health care may be the best in the world. Yet an increasing proportion of its citizens would find this is an empty boast. Between 30 million and 40 million Americans now lack any health insurance, and another 50 million are inadequately covered. Current projections suggest that these numbers will increase. The American College of Physicians has therefore identified access as one of the most urgent problems besetting America's health care system.

Access to health care decreases as its costs go up, and up is where they have been going. America will spend about $\$ 650$ billion on health care this year compared with $\$ 75$ billion in 1970 , an estimated five fold increase when inflation is taken into account. Spiralling costs have generated ever greater pressures for cost containment, which have undermined the basic infrastructure on which the delivery of services depends-facilities and staff. Efforts by employers, the government, and third party payers to control rising costs are increasingly intruding on clinical decision making and are undermining doctor-patient relationships.

Current ways of paying for health care, entailing multiple 0 public and private insurers and third party payers, are complex, confusing, costly, wasteful, and intrusive. Coverage under both private insurance plans and public programmes (Medicare and Medicaid) is generally difficult to understand and requires complex mechanisms for dealing with claims. Patients and their families are burdened with extensive paperwork.

The need for reform seems undeniable-but where to begin? Because the problem of access is inextricably linked to $\frac{0}{0}$ several other substantial problems - such as the cost and quality of health care, resource allocation, doctors' dissatisfaction, burdensome problems for patients, malpractice, and the limitations of the health insurance industry - the college believes that only fundamental change will do. To 
evaluate various proposals for reform the college drew up a list of 16 criteria. ${ }^{1}$ It came down against throwing more money at the problem-as this could make things worse-and urged extreme caution over building on the present structure. What was needed was a thoughtful re-examination of the system of health care from top to bottom.

So far the college has decided that the solution will be a nationwide programme, and it wants such a programme adopted as a policy goal for the nation. The college's main focus now is to define further the systemic reforms that are needed. To make the reform of health care a reality the college has identified two primary objectives: to further an environment receptive to comprehensive reform and to speak from a well informed position. On each of the main issuescontaining costs, controlling use, determining benefits, deciding on mechanisms of financing, and reducing administrative costs - work is continuing deliberately and carefully.

According to the American College of Physicians nothing short of universal access to basic health care will be fair in the long run. How that goal is achieved has yet to be determined, although the college believes that it has identified its principal elements and proposed some realistic options. These are currently being reviewed by the members of the college, and the final proposals should be published next spring. America, it believes, can one day develop a system that is fair and equitable for all.

NORTON J GREENBERGER President 1990-1

NICHOLAS E DAVIES* President Elect 1990-1

EUEGENE A HILDRETH

American College of Physicians, Chairman, Board of Regents 1990-1

USA

(Correspondence to Dr Greenberger, Department of Medicine, University of Kansas Medical Centre, Kansas City, Kansas 66103, USA)

$\star$ Dr Davies died earlier this year.

1 American College of Physicians. Access to health care. Ann Intern Med 1990;112:641-61.

\section{Does triamterene cause renal calculi?}

\section{Not enough evidence yet to tell patients to stop taking triamterene}

Over two million prescriptions for triamterene were issued in the United Kingdom last year so the possibility that this drug may cause renal calculi is important. As a potassium sparing diuretic triamterene is often prescribed in conjunction with a thiazide and acts on the distal tubule to inhibit reabsorption of sodium in exchange for potassium and hydrogen ions. Taken by mouth it is rapidly metabolised to parahydroxytriamterene and then to parahydroxytriamterene sulphate. Half of the drug is excreted in the urine, $20 \%$ as triamterene and $80 \%$ as metabolite. ${ }^{1}$

A case report in 1979 suggested the lithogenic properties of triamterene, ${ }^{2}$ and this was followed by the observation of an abnormal urinary sediment in patients and volunteers taking the drug. ${ }^{3}$ The sediment, resembling granular casts, was often deep brown and accompanied by hyaline casts, some of which were covered with small birefringent crystals; larger round brown bodies, appearing as Maltese crosses under polarised light, were also seen. This abnormal urinary sediment occurs in about half of all patients treated. ${ }^{+}$The crystals appear in the urine two to four hours after ingestion of the drug, and animal studies show that birefringent crystals and casts form within the medullary and papillary collecting ducts of the kidney. ${ }^{5}$ This site of formation is supported by the histological findings in a patient who developed acute interstitial nephritis after massive intoxication with triamterene and hydrochlorothiazide. Tubular plugging by crystal laden tubular cells was found in renal tissue, although the crystals were not positively identified as containing triamterene or a metabolite. ${ }^{6}$ Nevertheless, only one definite case of interstitial nephritis induced by triamterene has been reported.

The presence of triamterene in a calculus may be suspected by blue fluorescence $(440 \mathrm{~nm})$ under long wave ultraviolet light, but thin layer chromatography ${ }^{8}$ or infrared spectroscopy provides definitive analysis. ${ }^{1}$ The composition of the stones varies: half of 66 stones containing triamterene were found to contain less than $5 \%$ and none contained more than $75 \%$ of material derived from the drug. ${ }^{8}$ Triamterene itself, rather than its more abundant metabolites, was the commonest constituent. Others have also identified stones made mostly from triamterene ${ }^{9}$ and Carr et al found that $21 \%$ of stones containing triamterene were made exclusively of it. ${ }^{1}$ In the remainder triamterene was associated with calcium oxalate monohydrate and dihydrate, apatite, or uric acid.

But do these data mean that triamterene or its metabolites cause the stones? Triamterene is not invariably found at the core of every stone, ${ }^{1}$ and Werness et al showed that triamterene and metabolites have no effect on calcium oxalate monohydrate, hydroxyapatite, or uric acid crystal systems, although they bind strongly to protein matrix. ${ }^{10}$ In contrast, White and Nancollas showed that triamterene and its metabolites could induce growth of crystals in supersaturated solutions of calcium oxalate monohydrate. ${ }^{11}$ The clinical relevance of these in vitro findings is not clear, and, most importantly, stones in the urinary tracts of patients taking triamterene do not always contain the drug. ${ }^{12}$

If crystalluria and casts are common sequelae to ingestion of triamterene might absorption or excretion be perhaps different in patients in whom stones form? Carey et al found no difference in absorption or excretion of triamterene in such patients, ${ }^{13}$ and this was confirmed by Ettinger, who also found no difference between patients and controls in total recovery, hourly excretion patterns, or concentration of triamterene or parahydroxytriamterene in the urine.$^{1+}$ The $\mathrm{pH}$ of urine does not seem to affect the solubility of triamterene or its sulphate metabolite. ${ }^{1}$ More relevantly, Carey et al point out that those in whom calculi form early during treatment and with a family history are more prone to further calculi; this may explain their observation of a $35 \%$ incidence of previous renal calculi in patients who developed calculi while being treated with triamterene compared with a $4 \%$ incidence of previous calculi in patients who did not. ${ }^{13}$ So perhaps the patient, rather than the drug, is the risk factor.

A specific lithogenic role for triamterene, and possibly its metabolites, remains unproved, although the occurrence of stones rich in triamterene must tend to support one. The evidence is not strong enough to warrant patients with a history of recurrent renal calculi avoiding taking the drug, but with increasing use further epidemiological information may become available. Currently in one reference laboratory stones containing triamterene are as common as cystine 